\title{
Maternal and paternal contribution to intergenerational recurrence of breech delivery: population based cohort study
}

\section{Tone Irene Nordtveit, PhD student, ${ }^{1}$ Kari Klungsoyr Melve, associate professor, ${ }^{1,2}$ Susanne Albrechtsen, obstetrician, ${ }^{3}$ Rolv Skjaerven, professor ${ }^{1,2}$}

${ }^{1}$ Section for Epidemiology and Medical Statistics, Department of Public Health and Primary Health Care, University of Bergen,

Postbox 7804, N-5020 Bergen, Norway

${ }^{2}$ Medical Birth Registry, Norwegian Institute of Public Health, Norway

${ }^{3}$ Department of Obstetrics and Gynaecology, Haukeland University Hospital, N-5021

Bergen, Norway

Correspondence to: Tone Irene

Nordtveit

Tone.Nordtveit@isf.uib.no

doi:10.1136/bmj.39505.436539.BE

\section{ABSTRACT}

Objective To investigate intergenerational recurrence of breech delivery, with a hypothesis that both women and men delivered in breech presentation contribute to increased risk of breech delivery in their offspring.

Design Population based cohort study for two generations.

Setting Data from the medical birth registry of Norway, based on all births in Norway 1967-2004 (2.2 million births).

Participants Generational data were provided through linkage by national identification numbers, forming 451393 mother-offspring units and 295253 fatheroffspring units. We included units where both parents and offspring were singletons and offspring were first born, forming 232704 mother-offspring units and 154851 father-offspring units for our analyses.

Main outcome measure Breech delivery in the second generation.

Results Men and women who themselves were delivered in breech presentation had more than twice the risk of breech delivery in their own first pregnancies compared with men and women who had been cephalic presentations (odds ratios $2.2,95 \%$ confidence interval 1.8 to 2.7 , and $2.2,1.9$ to 2.5 , for men and women, respectively). The strongest risks of recurrence were found for vaginally delivered offspring and were equally strong for men and women. Increased risk of recurrence of breech delivery in offspring was present only for parents delivered at term.

Conclusion Intergenerational recurrence risk of breech delivery in offspring was equally high when transmitted through fathers and mothers. It seems reasonable to attribute the observed pattern of familial predisposition to term breech delivery to genetic inheritance, predominantly through the fetus.

\section{INTRODUCTION}

Breech delivery is a challenge in obstetric management and is associated with considerably increased perinatal mortality and morbidity. ${ }^{1-3}$ In most studies, the prevalence of breech delivery ranges from $3 \%$ to $4 \% .{ }^{4-7}$ The aetiology of breech delivery - that is, the causes of failure of spontaneous cephalic version-is not clear, but several factors are associated with an increased risk of breech delivery, such as first baby, older mother, and low gestational age and low birth weight. ${ }^{4-8}$ Mechanical factors, such as uterine malformations, pelvic tumours, site of placental attachment, and low volume of amniotic fluid, also increase the risk of breech delivery. ${ }^{8-11}$ Furthermore, infants with congenital anomalies more often present in breech at delivery. ${ }^{5-7910}$ Such aetiological factors, however, are identified in only $7-15 \%$ of breech deliveries. ${ }^{81012}$

Though recurrence of breech delivery in successive siblings is high, ${ }^{8101213}$ knowledge of recurrence between generations is lacking. Cartledge and Hancock first proposed a genetic predisposition to breech delivery in 1942, using a family inheritance chart. ${ }^{14}$ Intergenerational recurrence is plausible if genes are aetiologically important to its occurrence. Genes could work through two different pathways: fetal genes passed on from the mother or the father could increase the risk, and maternal genes, expressed in the daughters, acting on the mother's capability of carrying a pregnancy, could also enhance maternal susceptibility. ${ }^{15}$

We investigated intergenerational recurrence of breech delivery, with a hypothesis that women and men who themselves were delivered in breech presentation contribute to increased risk of breech delivery in their offspring.

\section{METHODS}

Population based generational data

We used data up to 2004 from the medical birth registry of Norway, a population based, compulsory registry of all births in Norway since 1967. The attending midwife fills in a standardised notification form comprising demographic data on the parents, maternal health before and during pregnancy, complications and interventions during delivery, and the condition of the newborn. The notification form was unchanged up to 1998 , when a new form based on checkboxes was introduced. Up to 1998 breech delivery was noted as a 
complication during delivery (specified in the instructions with the form) and as a specific checkbox thereafter.

All live births and stillbirths of at least 16 weeks of gestation are registered, which in 2003 amounted to 2.2 million births. The national identification number is unique to all inhabitants of Norway and is provided soon after birth by the population registry of Norway. Routine record linkage between the birth registry and the population registry is established by means of the mother's identification number. These procedures ensure near complete ascertainment of births in the birth registry.

Births were linked to the birth records of the mother and father by the national identification numbers, thus providing generation files with birth records on mothers and their offspring (451393 records) and fathers and their offspring (295253 records). We considered all births delivered in breech presentation as breech delivery, irrespective of mode of delivery, thus including both elective and emergency caesarean section. We excluded multiple pregnancies and births of infants less than $500 \mathrm{~g}$ in both generations. For all analyses, we restricted the study to first born offspring in the second generation, which left us with a population of 232704 mother-offspring units and 154851 father-offspring units. As women are generally younger than men at childbirth, and as some fathers (around 2\%) are not reported, the number of mothers in the birth registry is considerably higher than the number of fathers. All the mothers and fathers were born during 1967-86. In the second generation, more than $98 \%$ of the offspring were born during 1987-2004.

We used these data to study whether women and men delivered in breech presentation had a higher risk of breech delivery in their offspring than those delivered in cephalic presentation. As possible confounding and effect modifying variables we evaluated

\begin{tabular}{|c|c|c|c|c|c|c|}
\hline & \multicolumn{3}{|c|}{ Females } & \multicolumn{3}{|c|}{ Males } \\
\hline & Total* & No (\%) breech & Odds ratio $(95 \% \mathrm{Cl})$ & Total* & No (\%) breech & Odds ratio $(95 \% \mathrm{Cl})$ \\
\hline \multicolumn{7}{|l|}{ Birth order: } \\
\hline 1 & 92341 & $3198(3.5)$ & 1.8 (1.7 to 1.9$)$ & 60933 & $1571(2.6)$ & 1.7 (1.6 to 1.8$)$ \\
\hline$\geq 2$ & 140363 & $2683(1.9)$ & $1 \dagger$ & 93918 & $1449(1.5)$ & $1 \dagger$ \\
\hline \multicolumn{7}{|c|}{ Gestational age (weeks): } \\
\hline$\geq 37$ & 215625 & $5133(2.4)$ & $1 \dagger$ & 142735 & $2585(1.8)$ & $1 \dagger$ \\
\hline$\ll 37$ & 8754 & $505(5.8)$ & 2.5 (2.3 to 2.8$)$ & 6797 & $324(4.8)$ & 2.7 (2.4 to 3.1$)$ \\
\hline \multicolumn{7}{|l|}{ Time period: } \\
\hline $1967-71$ & 118991 & $2710(2.3)$ & $1 \dagger$ & 91471 & $1738(1.9)$ & $1 \dagger$ \\
\hline $1972-6$ & 78395 & $2181(2.8)$ & 1.23 (1.16 to 1.30$)$ & 49505 & $988(2.0)$ & 1.05 (0.97 to 1.14$)$ \\
\hline $1977-81$ & 29635 & $832(2.8)$ & 1.24 (1.15 to 1.34$)$ & 12636 & $266(2.1)$ & 1.11 (0.97 to 1.27$)$ \\
\hline $1982-6$ & 5683 & $158(2.8)$ & $1.23(1.04$ to 1.44$)$ & 1239 & $28(2.3)$ & $1.19(0.82$ to 1.74$)$ \\
\hline \multicolumn{7}{|c|}{ Maternal education: } \\
\hline Low & 71025 & $1652(2.3)$ & $1 \dagger$ & 47038 & $906(1.9)$ & $1 \dagger$ \\
\hline Medium & 126833 & $3256(2.6)$ & 1.11 (1.04 to 1.18$)$ & 83695 & 1607 (1.9) & $1.00(0.92$ to 1.08$)$ \\
\hline High & 33768 & $942(2.8)$ & 1.21 (1.11 to 1.31$)$ & 23459 & $492(2.1)$ & 1.09 (0.98 to 1.22$)$ \\
\hline \multicolumn{7}{|l|}{ Maternal age: } \\
\hline$<20$ & 27757 & $808(2.9)$ & 1.22 (1.12 to 1.32$)$ & 18187 & $405(2.2)$ & 1.15 (1.02 to 1.30$)$ \\
\hline $20-24$ & 92333 & $2450(2.7)$ & 1.11 (1.04 to 1.18$)$ & 61689 & $1237(2.0)$ & 1.04 (0.95 to 1.13$)$ \\
\hline $25-29$ & 66827 & $1609(2.4)$ & $1 \dagger$ & 44493 & $862(1.9)$ & $1 \dagger$ \\
\hline $30-34$ & 29770 & $676(2.3)$ & 0.94 (0.86 to 1.03$)$ & 19574 & $312(1.6)$ & $0.82(0.72$ to 0.93$)$ \\
\hline$\geq 35$ & 16017 & $338(2.1)$ & 0.87 (0.78 to 0.98$)$ & 10908 & 204 (1.9) & 0.97 (0.83 to 1.13$)$ \\
\hline \multicolumn{7}{|c|}{ Birth weight by gestational age: } \\
\hline Small & 30460 & $1314(4.3)$ & 1.12 (1.03 to 1.21$)$ & 18607 & $600(3.2)$ & 1.04 (0.92 to 1.17$)$ \\
\hline Appropriate & 173262 & $4052(2.3)$ & $1 \dagger$ & 115269 & $2089(1.8)$ & $1 \dagger$ \\
\hline Large & 18831 & $291(1.5)$ & 0.97 (0.88 to 1.06$)$ & 13994 & $206(1.5)$ & 1.08 (0.96 to 1.23$)$ \\
\hline \multicolumn{7}{|l|}{ Major anomaly: } \\
\hline Absent & 230696 & $5735(2.5)$ & $1 \dagger$ & 153467 & $2961(1.9)$ & $1 \dagger$ \\
\hline Present & 2008 & $146(7.3)$ & 3.1 (2.6 to 3.6$)$ & 1384 & $59(4.3)$ & 2.3 (1.7 to 2.9$)$ \\
\hline \multicolumn{7}{|c|}{ Mode of delivery: } \\
\hline Vaginal & 225956 & $5185(2.3)$ & $1 \dagger$ & 150666 & $2737(1.8)$ & $1 \dagger$ \\
\hline Caesarean & 6748 & $696(10.3)$ & $4.9(4.5$ to 5.3$)$ & 4185 & $283(6.8)$ & $3.9(3.5$ to 4.4$)$ \\
\hline Total & 232704 & $5881(2.5)$ & - & 154851 & $3020(2.0)$ & - \\
\hline
\end{tabular}

*Numbers do not always add up to total because of missing values.

†Reference category. 
gestational age, birth order, mode of delivery, birth weight by gestational age, period of birth, maternal age, and maternal education.

We also linked records of mother, father, and offspring, yielding 148692 study units to study the effect on occurrence of breech delivery in offspring if both parents had been delivered in breech presentation.

Data on mode of delivery differentiating between elective and emergency caesarean section were available from 1988; thus generational data were slightly

Table 2 | Risk of breech delivery in first born offspring (2nd generation) of mothers and fathers (1st generation) by their own presentation at birth. Norway, 1967-2004

\begin{tabular}{|c|c|c|c|c|}
\hline \multirow{2}{*}{$\begin{array}{l}\text { Gestation and birth } \\
\text { order (1st } \\
\text { generation) }\end{array}$} & \multirow[b]{2}{*}{ No of offspring } & \multirow[b]{2}{*}{$\begin{array}{c}\text { No (\%) of breech } \\
\text { offspring }\end{array}$} & \multicolumn{2}{|c|}{ Odds ratio $(95 \% \mathrm{Cl})$} \\
\hline & & & Crude & Adjusted* \\
\hline \multicolumn{5}{|c|}{ Mother's own presentation at birth } \\
\hline \multicolumn{5}{|l|}{$\geq 37$ weeks, first: } \\
\hline Breech & 2797 & $237(8.5)$ & 2.2 (1.9 to 2.5$)$ & 2.2 (1.9 to 2.5$)$ \\
\hline Cephalic & 82569 & $3376(4.1)$ & $1.0 \S$ & $1.0 \S$ \\
\hline \multicolumn{5}{|c|}{$\geq 37$ weeks, subsequent: } \\
\hline Breech & 2336 & $163(7.0)$ & 1.7 (1.5 to 2.1$)$ & 1.7 (1.5 to 2.0$)$ \\
\hline Cephalic & 127923 & $5271(4.1)$ & $1.0 \S$ & $1.0 \S$ \\
\hline \multicolumn{5}{|l|}{ «37 weeks, first: } \\
\hline Breech & 274 & $16(5.8)$ & 1.3 (0.8 to 2.2$)$ & $1.4(0.8$ to 2.4$)$ \\
\hline Cephalic & 3690 & $167(4.5)$ & $1.0 \S$ & $1.0 \S$ \\
\hline \multicolumn{5}{|c|}{ <37 weeks, subsequent: } \\
\hline Breech & 231 & $10(4.3)$ & 1.1 (0.6 to 2.2$)$ & 1.1 (0.6 to 2.2$)$ \\
\hline Cephalic & 4559 & $175(3.8)$ & $1.0 \S$ & $1.0 \S$ \\
\hline \multicolumn{5}{|l|}{ Total†: } \\
\hline Breech & 5881 & $449(7.6)$ & 1.9 (1.8 to 2.1$)$ & 1.9 (1.8 to 2.1$)$ \\
\hline Cephalic & 226823 & 9265 (4.1) & $1.0 \S$ & $1.0 \S$ \\
\hline
\end{tabular}

Father's own presentation at birth

$\geq 37$ weeks, first:

\begin{tabular}{lcccc}
\hline Breech & 1351 & $119(8.8)$ & $2.2(1.8$ to 2.7$)$ & $2.2(1.8$ to 2.7$)$ \\
\hline Cephalic & 54742 & $2308(4.2)$ & $1.0 \S$ & $1.0 \S$ \\
\hline$\geq 37$ weeks, subsequent: & & & & \\
\hline Breech & 1234 & $82(6.6)$ & $1.6(1.3$ to 2.0$)$ & $1.6(1.3$ to 2.1$)$ \\
\hline Cephalic & 85408 & $3594(4.2)$ & $1.0 \S$ & $1.0 \S$ \\
\hline
\end{tabular}

\section{«37 weeks, first:}

\begin{tabular}{lcccc} 
Breech & 167 & $3(1.8)$ & $0.5(0.2$ to 1.5$)$ & 0.5 (0.2 to 1.6$)$ \\
\hline $\begin{array}{l}\text { Cephalic } \\
\text { 37 weeks, subsequent: }\end{array}$ & 2849 & $104(3.7)$ & $1.0 \S$ & $1.0 \S$ \\
\hline $\begin{array}{l}\text { Breech } \\
\text { Cephalic }\end{array}$ & 157 & $8(5.1)$ & $1.1(0.6$ to 2.4$)$ & $1.2(0.6$ to 2.5$)$ \\
\hline $\begin{array}{l}\text { Total†: } \\
\text { Breech }\end{array}$ & 3624 & $162(4.5)$ & $1.0 \S$ & $1.0 \S$ \\
\hline Cephalic & 3020 & $221(7.3)$ & $1.8(1.6$ to 2.1$)$ & $1.8(1.6$ to 2.1$)$ \\
\hline
\end{tabular}

Presentation at birth in both parents

Total†:

$\begin{array}{lcccc}\text { Breech } & 96 & 12(12.5) & 3.3(1.8 \text { to } 6.1) & 3.1 \text { (1.6 to 6.0) } \\ \text { Cephalic } & 148596 & 6121(4.1) & 1.0 \S & 1.0 \S\end{array}$

*Adjusted with logistic regression for birth weight by gestational age in 1st generation: small, appropriate, or large; period of birth 1st generation: 1967-71, 1972-6, 1977-81, 1982-6; maternal age 1st generation (years): $<20,20-24,25-29,30-34, \geq 35$; maternal education 1st generation: no high school, high school, beyond high school.

†Includes 8325 (3.6\%) mothers and 5319 (3.4\%) fathers with missing data on gestational age.

†These are also counted in upper part of table.

$\S$ Reference category. reduced $(2.2 \%$ mother-offspring units and $0.5 \%$ fatheroffspring units). Also, data for mode of delivery were missing for $0.4 \%$ of offspring of mothers and $0.5 \%$ of offspring of fathers.

Gestational age was estimated from the reported last menstrual period, and preterm birth was defined as delivery before 37 completed weeks of gestation. Data on gestational age were missing for $3.6 \%$ of the mothers, $3.4 \%$ of the fathers, and $6.0 \%$ and $5.0 \%$ of their offspring, respectively.

We classified birth weight for gestational age as small $(<10$ th centile), appropriate (10th-90th centile), and large $\left(>90\right.$ th centile). ${ }^{1617}$ When adjusting for growth, we also modelled growth as z scores of birth weight by gestational age in nine levels. Further, we adjusted for birth weight in nine $500 \mathrm{~g}$ categories.

Congenital anomalies were registered according to ICD-8 (international classification of diseases, eighth revision) for the years 1967-98 and ICD-10 thereafter. Any such diagnosis is made by paediatric examination during the initial stay at the birth clinic, and, since 1999, also during the stay at the neonatal ward for infants transferred to such units. Individuals were classified as having a registered major congenital anomaly or not, according to definitions used by the Eurocat (European Surveillance of Congenital Anomalies, www.eurocat. ulster.ac.uk).

Maternal education is the dimension of socioeconomic level that is most strongly and consistently associated with perinatal health. ${ }^{1819}$ We obtained data on maternal educational level from Statistics Norway based on the highest number of completed years of education and categorised as low (no high school), medium (high school), and high (beyond high school), according to national recommendations. ${ }^{20}$

\section{Paternal half siblings}

To specifically study effects transmitted through the fathers, we used the same birth registry records to identify paternal half siblings - that is, siblings with the same father and different mothers. We identified 35056 paternal half siblings whose father had changed partner between the births of his first two children, and both siblings were the first born offspring of the two mothers. We evaluated maternal age and education, offspring's period (year group) of birth, and offspring's gestational age as possible confounders.

\section{Statistical analysis}

We used SPSS version 14.0 and STATA version 9.0 for statistical analyses and calculated odds ratios and 95\% confidence intervals with contingency tables and by logistic regression. Logistic regression was used to estimate effects, adjust for confounding, and evaluate interaction between factors with odds ratios approximating relative risk. Relative risk modelling was used for the frequent outcomes with STATA.

\section{RESULTS}

The proportion of breech delivery registered in the birth registry was $2.5 \%$ in $1967-76,3.0 \%$ in $1977-86$, 
$3.2 \%$ in $1987-96$, and $3.5 \%$ in $1997-2004$. Among 318855 boys and 301438 girls born in 1967-76, $96.8 \%$ and $97.6 \%$, respectively, survived to the age of 18 . The mortality among those delivered in breech presentation was four times as high as among those delivered in cephalic presentation. The proportion of survivors who later gave birth or fathered a childwas lower for individuals delivered in breech presentation compared with cephalic presentation $(46 \%$ v 50\% for males $(\mathrm{P}<0.001)$ and $65 \%$ v $69 \%$ for females $(\mathrm{P}<0.001))$.

Table 1 presents the relation between different birth characteristics and breech delivery for females and males in the first generation. Primiparity, prematurity major congenital anomalies, and caesarean section were all strongly associated with breech delivery.

Breech delivery in offspring of men and women delivered in breech presentation

he highest risk of recurrence of breech delivery was observed in babies of first born men and women delivered in breech presentation at term (odds ratio $2.2,95 \%$ confidence interval 1.8 to 2.7 , and $2.2,1.9$ to 2.5 , respectively) (table 2). We found no recurrence between generations for men and women born preterm.

Table $3 \mid$ Risk of breech delivery in first born offspring (2nd generation) by presentation at birth of mother ${ }^{\star}$ and father* (1st generation) and mode of delivery and gestational age of offspring, Norway, 1967-2004

\begin{tabular}{|c|c|c|c|c|c|c|c|c|}
\hline & \multicolumn{4}{|c|}{ Offspring of mothers } & \multicolumn{4}{|c|}{ Offspring of fathers } \\
\hline & \multirow[b]{2}{*}{$\begin{array}{c}\text { No of } \\
\text { offspring }\end{array}$} & \multirow{2}{*}{$\begin{array}{l}\text { No (\%) of } \\
\text { breech } \\
\text { offspring }\end{array}$} & \multicolumn{2}{|c|}{ Relative risk $(95 \% \mathrm{Cl})$} & \multirow{2}{*}{$\begin{array}{c}\text { No of } \\
\text { offspring } \ddagger\end{array}$} & \multirow{2}{*}{$\begin{array}{l}\text { No (\%) of } \\
\text { breech } \\
\text { offspring }\end{array}$} & \multicolumn{2}{|c|}{ Relative risk $(95 \% \mathrm{Cl})$} \\
\hline & & & Crude & Adjusted $†$ & & & Crude & Adjusted $†$ \\
\hline \multicolumn{9}{|c|}{ Mode of delivery offspring: } \\
\hline \multicolumn{9}{|l|}{ Vaginal } \\
\hline $\begin{array}{c}\text { Breech } \\
\text { mother/father }\end{array}$ & 2330 & $91(3.9)$ & $\begin{array}{l}2.3 \text { (1.9 to } \\
2.9)\end{array}$ & $\begin{array}{l}2.3 \text { (1.9 to } \\
2.9)\end{array}$ & 1131 & $51(4.5)$ & 2.7 (2.0 to 3.5$)$ & 2.7 (2.0 to 3.5$)$ \\
\hline $\begin{array}{c}\text { Cephalic } \\
\text { mother/father }\end{array}$ & 70730 & $1192(1.7)$ & $1.0 \S$ & $1.0 \S$ & 47520 & $800(1.7)$ & $1.0 \S$ & $1.0 \S$ \\
\hline \multicolumn{9}{|c|}{ Elective section: } \\
\hline $\begin{array}{c}\text { Breech } \\
\text { mother/father }\end{array}$ & 108 & 69 (63.9) & $\begin{array}{c}1.2(1.1 \text { to } \\
1.4)\end{array}$ & $\begin{array}{c}1.2(1.1 \text { to } \\
1.4)\end{array}$ & 51 & $32(62.7)$ & $\begin{array}{c}1.2(0.96 \text { to } \\
1.5)\end{array}$ & $\begin{array}{c}1.2(0.94 \text { to } \\
1.5)\end{array}$ \\
\hline $\begin{array}{c}\text { Cephalic } \\
\text { mother/father }\end{array}$ & 1968 & $1028(52.2)$ & $1.0 \S$ & $1.0 \S$ & 1355 & $713(52.6)$ & $1.0 \S$ & $1.0 \S$ \\
\hline \multicolumn{9}{|c|}{ Emergency section: } \\
\hline $\begin{array}{c}\text { Breech } \\
\text { mother/father }\end{array}$ & 293 & $68(23.2)$ & $\begin{array}{c}1.8(1.5 \text { to } \\
2.3)\end{array}$ & $\begin{array}{c}1.8(1.5 \text { to } \\
2.3)\end{array}$ & 153 & $33(21.6)$ & $1.6(1.2$ to 2.2$)$ & 1.7 (1.2 to 2.3$)$ \\
\hline $\begin{array}{c}\text { Cephalic } \\
\text { mother/father }\end{array}$ & 7697 & $975(12.7)$ & $1.0 \S$ & $1.0 \S$ & 5346 & $701(13.1)$ & $1.0 \S$ & $1.0 \S$ \\
\hline \multicolumn{9}{|c|}{ Gestational age offspring: } \\
\hline \multicolumn{9}{|l|}{ «37 weeks } \\
\hline $\begin{array}{c}\text { Breech } \\
\text { mother/father }\end{array}$ & 189 & $26(13.8)$ & $\begin{array}{c}1.6(1.1 \text { to } \\
2.3)\end{array}$ & $\begin{array}{c}1.5(1.1 \text { to } \\
2.2)\end{array}$ & 99 & $16(16.2)$ & 1.7 (1.1 to 2.7$)$ & 1.7 (1.1 to 2.7$)$ \\
\hline $\begin{array}{c}\text { Cephalic } \\
\text { mother/father }\end{array}$ & 5393 & $476(8.8)$ & $1.0 \S$ & $1.0 \S$ & 3581 & $341(9.5)$ & $1.0 \S$ & $1.0 \S$ \\
\hline \multicolumn{9}{|l|}{ 37-38 weeks } \\
\hline $\begin{array}{c}\text { Breech } \\
\text { mother/father }\end{array}$ & 453 & $64(14.1)$ & $\begin{array}{c}2.0(1.6 \text { to } \\
2.6)\end{array}$ & $\begin{array}{l}2.0(1.6 \text { to } \\
2.5)\end{array}$ & 191 & $25(13.1)$ & $1.8(1.2$ to 2.6$)$ & 1.8 (1.2 to 2.6$)$ \\
\hline $\begin{array}{c}\text { Cephalic } \\
\text { mother/father }\end{array}$ & 11258 & $790(7.0)$ & $1.0 \S$ & $1.0 \S$ & 7905 & $574(7.3)$ & $1.0 \S$ & $1.0 \S$ \\
\hline \multicolumn{9}{|l|}{$39-40$ weeks } \\
\hline $\begin{array}{c}\text { Breech } \\
\text { mother/father }\end{array}$ & 1199 & $89(7.4)$ & $\begin{array}{l}2.0(1.6 \text { to } \\
2.5)\end{array}$ & $\begin{array}{l}2.0(1.6 \text { to } \\
2.5)\end{array}$ & 610 & $50(8.2)$ & 2.2 (1.7 to 2.9 ) & 2.2 (1.6 to 2.8$)$ \\
\hline $\begin{array}{c}\text { Cephalic } \\
\text { mother/father }\end{array}$ & 34627 & $1275(3.7)$ & $1.0 \S$ & $1.0 \S$ & 23842 & $896(3.8)$ & $1.0 \S$ & $1.0 \S$ \\
\hline \multicolumn{9}{|l|}{ 41-42 weeks } \\
\hline $\begin{array}{c}\text { Breech } \\
\text { mother/father }\end{array}$ & 715 & $37(5.2)$ & $\begin{array}{c}2.2 \text { (1.6 to } \\
3.0)\end{array}$ & $\begin{array}{c}2.2 \text { (1.6 to } \\
3.0)\end{array}$ & 343 & $24(7.0)$ & 2.8 (1.9 to 4.2$)$ & 2.7 (1.8 to 4.0$)$ \\
\hline $\begin{array}{c}\text { Cephalic } \\
\text { mother/father }\end{array}$ & 22643 & $539(2.4)$ & $1.0 \S$ & $1.0 \S$ & 15372 & $383(2.5)$ & $1.0 \S$ & $1.0 \S$ \\
\hline \multicolumn{9}{|c|}{$\begin{array}{l}\text { *Confined to first born mothers and fathers delivered at term. } \\
\text { †Adjusted by logistic regression for birth weight by gestational age } 1 \text { st generation: small, appropriate, or large; period of birth } 1 \text { st generation: } 1967- \\
71,1972-6,1977-81,1982-6 \text {; maternal age } 1 \text { st generation (years): }<20,20-24,25-29,30-34, \geq 35 \text {; maternal education } 1 \text { st generation: no high school, } \\
\text { high school, beyond high school. } \\
\text { ¥Total is lower than in table } 2 \text { because of offspring with missing data on mode of delivery and gestational age (see Methods) and exclusion of } \\
\text { gestational ages } \geq 43 \text { weeks in lower half of table }(2.6 \% \text { mother-offspring units and } 2.1 \% \text { father-offspring units). } \\
\text { §Reference category. }\end{array}$} \\
\hline
\end{tabular}


Adjustment for birth weight by gestational age, maternal age, maternal education, and period of birth, all in the first generation, only slightly affected the results (table 2). We found similar results for second or subsequent offspring in the second generation (results not tabulated).

When we stratified the analysis by mode of delivery of the offspring within the group of parents who were term and first born, we found the highest recurrence of breech delivery among those delivered vaginally. The recurrence through both men and women was lowest when offspring were delivered by elective caesarean section. Also, when we stratified by gestational age of the offspring, there was a tendency of higher recurrence with increasing gestational age (table 3 ). The strongest risk of recurrence was found for vaginally delivered offspring with gestational age 41-42 weeks (crude relative risk $3.3,1.9$ to 5.9 , and $3.3,2.2$ to 5.0 , for men and women, respectively) (results not tabulated).

The combination of both parents delivered in breech did not occur often but still gave a high risk of breech delivery in the next generation with a crude odds ratio of 3.3 (1.8 to 6.1 ), with the reference being both parents delivered in cephalic presentation (table 2).

We calculated the attributable risk for the offspring ${ }^{21}$ and found that $3 \%$ of the cases of breech delivery were attributable to breech delivery in the father and $3 \%$ were attributable to breech delivery in the mother. Thus $6 \%$ of the breech deliveries in the population offspring were accounted for by parental influence.

Low birth weight is associated with breech delivery. ${ }^{467}$ Recurrence of breech delivery in children of men and women themselves born with low birth weight, however, was found only among those parents delivered at term. For instance, in the subgroup of first born men and women with birth weight 2000-3000 g, the risk of recurrence was near the baseline risk for preterm breech delivery, whereas for term breech delivery the crude odds ratio was 2.2 (1.4 to 3.4) for men and 2.2 (1.7 to 2.9) for women. In fact, for both sexes, the association between term breech delivery and recurrence was remarkably stable, regardless of whether growth restriction (small for gestational age) was present or not (results not tabulated).

Recurrence of breech delivery was not influenced by whether the offspring in the second generation was registered with a major congenital anomaly. Women delivered at term in breech presentation and with a major anomaly, however, had an odds ratio of 4.1 (2.5 to 6.6) of delivering offspring in breech compared with women delivered at term in cephalic presentation without a major anomaly. The corresponding odds ratio for women delivered at term in breech presentation without a major anomaly was 1.9 (1.7 to 2.1$)$. The highest recurrence was found among women delivered at term in breech presentation with congenital dislocation of the hips, who had five times the risk of breech delivery in their offspring compared with women delivered at term in cephalic presentation without dislocation $(4.8,2.6$ to 9.0$)$. For men with a major anomaly, we did not find a significantly increased risk of recurrence compared with men without a major anomaly, although we observed a high point estimate for hip dislocation (2.8, 0.7 to 12.4).

\section{Breech delivery in paternal half siblings}

Women had an increased risk of breech delivery in their first pregnancy if they became pregnant by a man who had already fathered a breech first pregnancy in another woman relative to women whose partner had previously fathered a cephalic first pregnancy $(6.1 \% \mathrm{v}$ $4.2 \%$, odds ratio $1.5,1.2$ to 1.9$)$. Adjustment for maternal age and maternal education, offspring's period of birth, and offspring's gestational age only slightly changed the results $(1.4,1.1$ to 1.8$)$.

\section{DISCUSSION}

\section{Principal findings and interpretation}

Both women and men delivered in breech presentation contribute to increased risk of breech delivery in their own offspring. As the recurrence associated with the father's delivery was as strong as the recurrence from the mother's, we infer that fetal genes from either the mother or the father are strongly related to breech delivery in the next generation. The clearest expression of fetal genes predisposing to breech delivery might be among offspring of men who themselves were delivered in breech. ${ }^{15}$ Men delivered in breech presentation seem to carry genes predisposing to breech delivery that are then transferred to their offspring, increasing their partner's risk of breech deliveries. Such men are associated with a more than twofold increase in breech delivery in their partners.

Fetal genes can also be transmitted from women delivered in breech. In addition, women delivered in breech presentation potentially carry genes that influence maternal susceptibility. Such maternal genes can be expressed only in daughters. ${ }^{15}$ There may be physical characteristics of the mother influenced by genes that predispose to breech delivery-for example, the stature attained in adulthood, the shape and size of her pelvis, and mechanical factors, such as uterine malformations and placental implantation site.

Our results support the hypothesis that fetal genes passed on from either the mother or the father increase the risk of breech delivery. Contrary to what we might expect, the effect of maternal genes seems to be low as recurrence from mother to offspring, being a sum of the effect of fetal genes passed on from the mother plus maternal genes, is similar to the effect of fetal genes passed on from the father. ${ }^{15}$

Intergenerational recurrence of different birth outcomes could also be explained by environmental conditions that persist in a family over generations. We are not aware of any such environmental factors, however, that might explain the magnitude of our results-for instance, stratification on maternal education (low, medium, and high) gave similar effects in all three categories (results not tabulated).

Our results could be explained by a higher proportion of caesarean sections at lower gestational ages for offspring of individuals who themselves were delivered 
in breech. If so, the highest risk of recurrence should be among offspring delivered by elective caesarean section. When we stratified on mode of delivery in the second generation, however, we found the highest risk among vaginally delivered births. Also, when we stratified the analysis by gestational age in the second generation, we found the highest risk for offspring delivered in week 41-42 rather than week 38-39, when elective caesarean section would be planned. This supports our hypothesis of a genetic component in the aetiology of breech delivery.

Recurrence of breech delivery among paternal half siblings supports the hypothesis of a fetal genetic component of breech delivery. Half siblings are second degree relatives, and the empirical risk of recurrence for the second infant is lower than if the infants had both parents in common. Still, men who fathered one breech pregnancy had about a $50 \%$ increased risk of fathering a breech pregnancy in a different woman, indicating a shared risk among paternal half siblings.

The familial association was mainly confined to breech delivery at term for both parents and offspring. This is in agreement with breech delivery in preterm pregnancies being a consequence of the preterm delivery itself and not genetic susceptibility to breech delivery. At lower gestational ages, the breech position is more likely to be a random event. ${ }^{5}$ Also, recurrence of preterm delivery is generally low through generations. $^{22}$

Birth weight is a product of a fetus' intrauterine growth rate and the length of gestation. Preterm infants naturally have low birth weight, whereas term infants with low birth weight are more likely growth restricted. Again, for men and women delivered in breech with low birth weight, the risk of breech delivery in their offspring was found among those parents delivered at term.

Being small for gestational age is a risk factor for breech delivery. ${ }^{10}$ There are acknowledged intergenerational associations in fetal growth rate, ${ }^{23}$ so recurrence of fetal growth might confound our results. Adjustment for the mother's and the father's growth, however, modelled as three categories (small, appropriate, and large for gestational age) or as z scores of birth weight by gestational age (nine categories) did not significantly change the results, nor did adjustment for birth weight in nine $500 \mathrm{~g}$ categories.

\section{Congenital anomalies}

Recurrence of breech delivery was not influenced by whether or not the offspring was registered with a major congenital anomaly. When women with a major anomaly were delivered in breech presentation, however, the risk of breech delivery in their offspring was significantly higher than for women delivered in breech presentation without a major anomaly. Women delivered in breech presentation with congenital hip dislocation had five times the risk of breech delivery in their own pregnancies compared with women delivered in cephalic presentation without dislocation. These associations were not similarly observed among men. One hypothesis might be that the morphological characteristics of the pelvis in women with congenital hip dislocation differ from those in women with normal hips, which in turn poses the potential risk of breech delivery in their offspring. To us, this would probably be a maternal genetic effect, though the main effect in our study still seems to be that the effect of maternal genes is less pronounced than the effect of fetal genes from mothers and fathers. Individuals with congenital hip dislocation and other congenital anomalies, however, constitute a small subgroup in this cohort.

\section{Strengths and limitations of the study}

Our cohort data were based on mandatory reporting to a population based registry over a 37 year period. The cohort design comprising the whole population reduces the possibility that selection bias can explain our results. The large study size and standardised collection of data provide high precision in the effect estimates.

Our data indicate a time trend in breech delivery, from $2.5 \%$ in the first generation to $3-4 \%$ in the offspring generation. Changes in the notification and registration of breech delivery in the birth registry could account for this, together with demographic changes in terms of increasing proportion of births with low birth order, caesarean section, and high maternal age. $^{4}$

The parental cohort includes only survivors and those reproducing, while the offspring cohort is complete. Breech delivery was associated with increased mortality up to the age of 18. Among individuals who survived to 18 , the proportion who reproduced was lower for those delivered in breech than cephalic presentation, possibly linked to the excess of congenital anomalies among infants delivered in breech presentation. ${ }^{5-79} 102425$

\section{Conclusions and implications for clinicians}

Genes passed on from either the mother or the father to the fetus seem to be closely related to breech delivery. Breech delivery is associated with increased perinatal

\section{WHAT IS ALREADY KNOWN ON THIS TOPIC}

Breech delivery is associated with significantly increased perinatal mortality and morbidity

Recurrence of breech delivery in successive siblings is high, but knowledge on recurrence between generations is lacking

\section{WHAT THIS STUDY ADDS}

Both men and women delivered in breech presentation at term contribute to increased risk of breech delivery in their offspring

Recurrence through the father is as strong as recurrence through the mother

Genes passed on from the father or the mother seem to be closely related to breech delivery 
mortality and morbidity. ${ }^{1-3}$ A considerable number of breech presentations are not detected before labour, despite careful antenatal surveillance. ${ }^{26}$ To avoid undiagnosed breech deliveries, information about the mother's and the father's own presentation at birth will be valuable in the evaluation of fetal presentation in the third trimester.

We thank Mette C Tollånes for her useful comments on an earlier version of this article.

Contributors: TIN, KKM, SA, and RS all substantially contributed to conception, design, and interpretation of data. TIN drafted the article and analysed data. All authors revised it critically for important intellectual content and gave their approval of the final version. RS is guarantor. Funding: Norwegian Medical Research Council.

Competing interests: None declared.

Ethical approval: Research ethics committees in Norway regularly exempt research on anonymous data from ethical review.

Provenance and peer review: Not commissioned; externally peer reviewed.

1 Albrechtsen S, Rasmussen S, Dalaker K, Irgens LM. Perinatal mortality in breech presentation sibships. Obstet Gynecol 1998;92:775-80.

2 Herbst A. Term breech delivery in Sweden: mortality relative to fetal presentation and planned mode of delivery. Acta Obstet Gynecol Scand 2005;84:593-601.

3 Danielian PJ, Wang J, Hall MH. Long-term outcome by method of delivery of fetuses in breech presentation at term: population based follow up. BMI 1996;312:1451-3.

4 Albrechtsen S, Rasmussen S, Dalaker K, Irgens LM. The occurrence of breech presentation in Norway 1967-1994. Acta Obstet Gynecol Scand 1998;77:410-5.

5 Bartlett D, Okun N. Breech presentation: a random event or an explainable phenomenon? Dev Med Child Neurol 1994;36:833-8.

6 Cruikshank DP. Breech presentation. Clin Obstet Gynecol 1986;29:255-63.

7 Rayl J, Gibson PJ, Hickok DE. A population-based case-control study of risk factors for breech presentation. Am J Obstet Gynecol 1996;174:28-32.

8 Tompkins P. An inquiry into the causes of breech presentation. Am J Obstet Gynecol 1946;51:595-606.

9 Braun FH, Jones KL, Smith DW. Breech presentation as an indicator of fetal abnormality. J Pediatr 1975;86:419-21.
10 Luterkort M, Persson PH, Weldner BM. Maternal and fetal factors in breech presentation. Obstet Gynecol 1984;64:55-9.

11 Ben-Rafael Z, Seidman DS, Recabi K, Bider D, Mashiach S. Uterine anomalies. A retrospective, matched-control study. J Reprod Med 1991;36:723-7.

12 Dunn LJ, Vanvoorhis L, Napier J. Term breech presentation; a report of 499 consecutive cases. Obstet Gynecol 1965;25:170-6.

13 Albrechtsen S, Rasmussen S, Dalaker K, Irgens LM. Reproductive career after breech presentation: subsequent pregnancy rates, interpregnancy interval, and recurrence. Obstet Gynecol 1998;92:345-50.

14 Cartledge LJ, Hancock FY. Inherited breech presentation. J Heredity 1942;33:409-10.

15 Lie RT. Intergenerational exchange and perinatal risks: a note on interpretation of generational recurrence risks. Paediatr Perinat Epidemiol 2007;21(suppl 1):13-8.

16 Skjaerven R, Gjessing HK, Bakketeig LS. Birthweight by gestational age in Norway. Acta Obstet Gynecol Scand 2000;79:440-9.

17 Lubchenco LO, Hansman C, Dressler M, Boyd E. Intrauterine growth as estimated from liveborn birth-weight data at 24 to 42 weeks of gestation. Pediatrics 1963;32:793-800.

18 Bloomberg L, Meyers J, Braverman MT. The importance of social interaction: a new perspective on social epidemiology, social risk factors, and health. Health Educ Q 1994;21:447-69.

19 Kramer MS, Seguin L, Lydon J, Goulet L. Socio-economic disparities in pregnancy outcome: why do the poor fare so poorly? Paediatr Perinat Epidemiol 2000;14:194-210.

20 Statistics Norway. Norwegian standard for educational grouping NC. 2000. www.ssb.no/emner/04/90/nos_c617/.

21 Rothman KJ. Epidemiology. An introduction. Oxford: Oxford University Press, 2002.

22 Magnus P, Bakketeig LS, Skjaerven R. Correlations of birth weight and gestational age across generations. Ann Hum Biol 1993;20:231-8.

23 Jaquet DD, Swaminathan SS, Alexander GRGR, Czernichow PP, Collin DD, Salihu HMHM, et al. Significant paternal contribution to the risk of small for gestational age. BJOG 2005;112:153-9.

24 Skjaerven R, Wilcox AJ, Lie RT. A population-based study of survival and childbearing among female subjects with birth defects and the risk of recurrence in their children. N Engl J Med 1999;340:1057-62.

25 Lie RT, WilcoxAl, Skjaerven R. Survival and reproduction among males with birth defects and risk of recurrence in their children. JAMA 2001;285:755-60.

26 Backe B, Nakling J. Effectiveness of antenatal care: a population based study. Br J Obstet Gynaecol 1993;100:727-32.

Accepted: 21 February 2008 